\title{
Triatominium search and diagnosis of trypanosoma cruzi in vectors captured in cane calk originating from sugarcane industry
}

\author{
Pesquisa de triatomíneos e diagnóstico de trypanosoma cruzi em vetores capturados e caldo de cana \\ oriundos de engenhos de cana de açúcar
}

Búsqueda de triatomas y diagnóstico de trypanosoma cruzi en vectores capturados y calderos de azúcar originados en las industrias del azúcar

Received: 08/13/2021 | Reviewed: 08/22/2021 | Accept: 08/23/2021 | Published: 08/24/2021

\author{
Ismael Vinicius de Oliveira \\ ORCID: https://orcid.org/0000-0001-9489-4081 \\ Universidade Federal Rural do Semi-árido, Brazil \\ E-mail: ismael.oliveira66277@alunos.ufersa.edu.br \\ Ana Karolinne de Alencar França \\ ORCID: https://orcid.org/0000-0001-6976-754X \\ Universidade Federal Rural do Semi-árido, Brazil \\ E-mail:karol_alencarf@hotmail.com \\ Fracisco Sérvulo de Oliveira Carvalho \\ ORCID: https://orcid.org/0000-0002-3844-0461 \\ Universidade Federal Rural do Semi-árido, Brazil \\ E-mail: fservulo.ocarvalho@gmail.com \\ Sara Caroline Dantas Nunes \\ ORCID: https://orcid.org/0000-0001-5387-8739 \\ Universidade Federal Rural do Semi-árido, Brazil \\ E-mail: saracarolinecdn @gmail.com \\ João Matheus Caé da Rocha \\ ORCID: https://orcid.org/0000-0002-4109-4598 \\ Faculdade Nova Esperança de Mossoró, Brazil \\ E-mail: j.matheus6@gmail.com \\ Kevyn Danuway Oliveira Alves \\ ORCID: https://orcid.org/0000-0002-8794-1094 \\ Universidade do Estado do Rio Grande do Norte, Brazil \\ E-mail: kevynalves@alu.uern.br \\ Ana Carolyna Diógenes Bezerra \\ ORCID: https://orcid.org/0000-0001-8206-0629 \\ Universidade do Estado do Rio Grande do Norte, Brazil \\ E-mail: anacarolyna2000@gmail.com \\ Francisco Silvestre Brilhante Bezerra \\ ORCID: https://orcid.org/0000-0001-6484-143X \\ Universidade Federal Rural do Semi-Árido, Brazil \\ E-mail: silvestre@ufersa.edu.br \\ Karoline Mikaelle De Paiva Soares \\ ORCID: https://orcid.org/0000-0003-1578-3733 \\ Universidade Federal Rural do Semi-árido, Brazil \\ E-mail: karolinesoares@ufersa.edu.br \\ Ana Carla Diógenes Suassuna Bezerra \\ ORCID: https://orcid.org/0000-0002-1039-5187 \\ Universidade Federal Rural do Semi-árido, Brazil \\ E-mail: anacarla@ufersa.edu.br
}

\begin{abstract}
The objective of the study was to survey triatomines and diagnose Trypanosoma cruzi in captured vectors and sugarcane juice from sugarcane mills. $100 \%$ (3/3) of the active sugar cane mills in the study area were surveyed. An active and passive search of the vectors and research of $T$. cruzi in the feces of engorged triatomines by compression of the abdomen and for the juice in natura by sedimentation with Giemsa staining technique were carried out, where five samples per mill were collected, totaling 15 researched. As a result, in $100 \%(3 / 3)$ of the mills, 22 hematophagous triatomines were captured, with $41 \%(9 / 22)$ by passive search and $59 \%(13 / 22)$ by active search. $81.8 \%(18 / 22)$ were found in the household environment and $18.2 \%(04 / 22)$ in the intra-household environment of the mills. Two species were
\end{abstract}


identified being $68.18 \%$ (15/22) Triatoma brasiliensis and 9.09\% (02/22) Triatoma pseudomaculata, with one adult and the four nymphs unable to be identified. T. cruzi diagnosis for triatomines was observed $4.54 \%$ (1/22) positive and $95.45 \%(21 / 22)$ negative, while broth, $100 \%$ (15/15) negative. However in $33.3 \%(5 / 15)$ broth samples the presence of soiling (microplastics) was observed. Demonstrating the importance of investigation and monitoring of milling sites with the possibility of oral transmission, which currently represent the majority of infection records in Brazil.

Keywords: Chagas Disease; Triatominae; Food safety.

\section{Resumo}

O objetivo do estudo foi pesquisar triatomíneos e diagnosticar Trypanosoma cruzi em vetores capturados e caldo de cana oriundos de engenhos de cana de açúcar. Foram pesquisados 100\% (3/3) dos engenhos ativos na área de estudo. Realizou-se busca ativa e passiva dos vetores e pesquisa de T. cruzi nas fezes dos triatomíneos ingurgitados por compressão do abdômen e para o caldo in natura por sedimentação com técnica de coloração com Giemsa, onde se coletou cinco amostras por engenho totalizando 15 pesquisadas. Como resultados em 100\% (3/3) dos engenhos foram capturados triatomíneos hematófagos totalizando 22 vetores, com $41 \%(9 / 22)$ por busca passiva e 59\% (13/22) ativa. Encontrados nos ambientes peridomiciliar 81,8\% (18/22) e 18,2\% (04/22) intradomiciliar do engenho. Duas espécies foram identificadas sendo 68,18\% (15/22) Triatoma brasiliensis e 9,09\% (02/22) Triatoma pseudomaculata, com um adulto e as quatro ninfas sem possibilidade de identificação. O diagnóstico de $T$. cruzi para os triatomíneos foi observado $4,54 \%$ (1/22) positivos e 95,45\% (21/22) negativos, enquanto que o caldo, $100 \%$ (15/15) negativas. Entretanto em $33,3 \%$ (5/15) amostras de caldo foram observadas presença de sujidades (microplásticos). Demonstrando a importância de investigação e acompanhamento dos locais de moagem com possibilidade de transmissão por via oral, que atualmente representam a maioria dos registros de infecção no Brasil.

Palavras-chave: Doença de Chagas; Triatominae; Segurança alimentar.

\section{Resumen}

El objetivo del estudio fue estudiar los triatominos y diagnosticar el Trypanosoma cruzi en los vectores capturados y en el jugo de caña de azúcar de los ingenios. Se encuestó al 100\% (3/3) de los molinos activos en la zona de estudio. Se realizó la búsqueda activa y pasiva de los vectores y la investigación de $T$. cruzi en las heces de los triatominos engordados por compresión del abdomen y del jugo in natura por sedimentación con la técnica de tinción de Giemsa, donde se recogieron cinco muestras por molino, totalizando 15 investigados. En el 100\% (3/3) de los molinos se capturaron 22 triatominos hematófagos, con un $41 \%$ (9/22) por búsqueda pasiva y un 59\% (13/22) por búsqueda activa. Se encontraron en el entorno peri-domiciliario $81,8 \%(18 / 22)$ y $18,2 \%(04 / 22)$ en el entorno intradomiciliario de los molinos. Se identificaron dos especies, siendo el 68,18\% (15/22) Triatoma brasiliensis y el 9,09\% (02/22) Triatoma pseudomaculata, con un adulto y las cuatro ninfas no identificables. El diagnóstico de T. cruzi para los triatominos se observó 4,54\% (1/22) positivo y 95,45\% (21/22) negativo, mientras que el caldo, 100\% (15/15) negativo. Sin embargo, en el 33,3\% (5/15) de las muestras de caldo se observó la presencia de suciedad (microplásticos). Demostrando la importancia de la investigación y el monitoreo de los sitios de molienda con posibilidad de transmisión oral, que actualmente representan la mayoría de los registros de infección en Brasil.

Palabras clave: Enfermedad de Chagas; Triatominae; Seguridad alimentaria.

\section{Introduction}

Chagas Disease caused by the protozoan Trypanosoma cruzi can be considered one of the most important pathologies in America (Santana et al. 2019), with millions of people infected, mainly in Latin America (Briceño-León et al. 2007). In Brazil, when related to chronic cases the disease presents three million people affected, and increase in acute cases of pathology by ingestion of contaminated food (Brsil, 2019).

The oral infection route has configured the main form of transmission and a serious public health problem (Menezes, et al. 2019), due to the increase in the rates of the disease from 129 cases (2012) to 298 cases (2016) (Brasil, 2019). Among the foods, the contamination of the pulp or juice of açai (Euterpe oleracea) stands out, which during the period from 2007 to 2016 had an increase of $99.57 \%$. Associated with the contamination of sugarcane juice, patuá (Oenocarpus bataua), buriti (Mauritia flexuosa) and bacaba (Oenocarpus bacaba) (Ferreira, et al. 2018).

In 2016, the Secretariat of Public Health of the State of Rio Grande do Norte (SESAP-RN) conducted an investigation in the municipalities of Alexandria, Marcelino Vieira, Pilões and Tenente Ananias, in order to confirm and notify cases associated with an outbreak of Chagas disease. According to SESAP-RN, the cases were mainly related to the ingestion of 
sugarcane juice during the milling periods in the aforementioned region, making them risk areas (SESAP-RN, 2020). Thus, the objective of the study was to survey triatomines and diagnose T. cruzi in captured vectors and sugarcane juice from sugarcane mills.

\section{Methodology}

During a one-year period, a survey was conducted in the rural area of the municipality of Marcelino Vieira, Rio Grande do Norte (RN), in 100\% (3/3) of the active sugarcane mills in the study area. This is considered one of the main local economic activities.

In the passive search, light traps were used and installed on the mills between 5:00 pm and 5:30 am for three consecutive days each month. The active search was carried out by means of a thorough inspection in all areas of the mills. In the intra-household, crevices or frechas, storage space, production and disposal of sugarcane bagasse were searched. In the peridomestic areas animal nests, bark and hollow tree trunks (Galvão et al, 2014). And when present inspection in piles of tiles and bricks, stone and wood fences (Jurber et al, 2014).

The identification of hematophagous vectors was performed according to the classification of Lent \& Wigodzinski (Lent Et Al. 1979). The investigation of T. cruzi positivity in the feces of engorged triatomines was performed by compression of the abdomen and fresh examination. Associated with the dissection of the beetle for definitive verification with analysis of the digestive tract, examining it under an optical microscope with the duodenum macerated with two drops of saline solution (Magallón-Gastélum et al, 1998).

For the parasitological analyses of the sugarcane juice, five samples per mill were collected, totaling 15 broths surveyed. Two analyses were performed for each sample. The first was performed using the conventional spontaneous sedimentation method (Lutz, 1919) where $200 \mathrm{ml}$ of the juice was homogenized with $50 \mathrm{ml}$ of distilled water, sieved and placed in goblets for sedimentation. The second was performed according to Pinto et al. (1990) methodology where 2.0 ml of broth was measured and transferred to falcon tubes and then centrifuged (1500 rpm/3 minutes). The sediment was smeared and fixed in methanol for 3 minutes and stained with Giemsa for 30 minutes with subsequent visualization under a microscope (Pinto et al, 1990).

\section{Results}

During the collection period it was observed that in $100 \%(3 / 3)$ of the mills hematophagous triatomines were captured in a total of 22 vectors being $41 \%(9 / 22)$ by passive search and 59\% (13/22) active. With 81.8\% (18/22) found in the home environment and $18.2 \%(04 / 22)$ in the home environment.

Among the triatomines collected $81.8 \%$ (18/22) were adults and $18.2 \%(04 / 22)$ were nymphs. For one adult specimen and four nymphs it was not possible to identify, however, 17 specimens were identified being 68.18\% (15/22) Triatoma brasiliensis and $9.09 \%$ (02/22) Triatoma pseudomaculata.

As for the diagnosis of $T$. cruzi in the vectors, $4.54 \%$ (1/22) were positive and $95.45 \%(21 / 22)$ negative. In the fresh broth, $100 \%(15 / 15)$ of the samples were negative; however, in 33.3\% (5/15), the presence of dirt (microplastics) was observed.

\section{Discussion}

Hematophagous triatomines were captured in all active mills, totaling 22 vectors. The diagnosis is related to the presence of the mills near the natural habitat of these insects. Where infestation can occur accidentally during the process of harvesting, storage, transport or processing of sugarcane (De Mattos et al., 2019). 
In the search for triatomines, $18.2 \%(04 / 22)$ were found in the interior of the mill. The lack of maintenance in the structure of this environment can cause the presence of fissures in the walls, which makes the intra-household conducive to habitat similar to wild rock shelters (Lorenzo et al., 2000).

Among the species collected, T. brasiliensis stood out. It is a common vector in the Northeastern states, with a predominant characteristic, potentially invasive and difficult to control (Dias et al., 2000). They are found in the peridomicile of places near the forest and in the intradomicile attracted by light sources (Neves et al, 2016). While the other species identified was T. pseudomaculata, it stands out for its ease of adapting to high temperature environments, such as the semi-arid region of the Northeast (Argolo et al, 2008). In the mills, it may have been diagnosed by various factors such as the presence of hiding places between the storage sites of sugarcane, arranged on the ground in all the mills surveyed.

As for the positivity of the protozoan T. cruzi, it was diagnosed in $4.54 \%$ of the captured vectors. The vector presence in mills, production and distribution of broths causes a public health alert by the possibility of food contamination associated mainly with the hygienic-sanitary conditions of the environment (De Mattos et al, 2019). However, in the analyzed fresh broth, $100 \%$ of the samples were negative for T. cruzi parasite diagnosis.

In $33.3 \%$ of the sugarcane juice samples the presence of dirt (microplastics) was observed. Among the vulnerable situations found for food contamination, the hygienic-sanitary conditions of the production environments stood out, such as the absence of individual protection equipment and the manipulation of money and food at the same time. Research conducted with sugarcane juice produced by vendors, it was observed low hygienic-sanitary quality, where there was great precariousness of information and procedures, thus generating high rates of contaminants present (Prado et al, 2010).

With this, the National Health Surveillance Agency (ANVISA), constitutionalized the procedures for obtaining this broth, in order to avoid food contaminations in general, proposed and put into effect resolutions for food handling (Brasil, 2020).

\section{Conclusion}

The development of modern traps for vector research was relevant, with capture and positivity of hematophagous triatomines associated with the presence of dirt in the broth. This demonstrates the importance of investigating and monitoringsites with the possibility of oral transmission, which currently represent the majority of infection records in Brazil.

\section{References}

Argolo, A. M., Felix, M., Pacheco, R., \& Costa, J. (2008). Chagas disease and its main vectors in Brazil, Imperial Novo Milênio. 67p.

Brazil. (2005). Ministry of Health. National Agency of Sanitary Surveillance. Resolution - RDC No. 218 of July 29, Technical regulation of Hygienic sanitary procedures for manipulation of foods and drinks prepared with vegetables. Diário Oficial [da] República Federativa do Brasil, Poder Executivo, http://www.anvisa.gov.br

Brazil. (2019) Ministry of Health: Secretariat of Health Surveillance. Panorama of Chagas disease in Brazil. Boletim Epidemiológico 36v.50. 15p.

Brazil. (2019) Ministry of Health. Secretariat of Health Surveillance. Acute Chagas disease and spatial distribution of triatomines of epidemiological importance, Brazil 2012 to 2016. Boletim Epidemiológico,50 (2). 10p.

Briceño-León, R., \& Galván, J. M. (2007) The social determinants of Chagas disease and the transformations of Latin America. Mem Inst Oswaldo Cruz. 102, $109-112$.

De Mattos, E. C. et al. (2019) Determination of Trypanosoma cruzi viability in experimentally contaminated acai pulp and sugarcane juice. BEPA, 16 (183), $15-23$

Dias, J. C. P. et al. (2000) General outline and perspectives of Chagas Disease in Northeastern Brazil. Cadernos de Saúde Pública, 16 (2), 13-34.

Santana et al. (2019) Oral Transmission of Trypanosoma cruzi, Brazilian Amazon. Emerging Infectious Diseases. 25 ( 1) $132-135$. 
Research, Society and Development, v. 10, n. 11, e96101119398, 2021

(CC BY 4.0) | ISSN 2525-3409 | DOI: http://dx.doi.org/10.33448/rsd-v10i11.19398

Ferreira R. T. B. et al. (2018) Detection and genotyping of Trypanosoma cruzi from açai products commercialized in Rio de Janeiro and Pará, Brazil. Parasites \& vectors, $11(1), 233$

Galvão, C., \& Juberg, J. (2014) External morphology of adults. Vectors of chagas disease in Brazil. Brazilian Society of Zoology - 33-39.

Jurberg, J et al. (2014) Iconographic Atlas of the Triatomines in Brazil (Vectors of Chagas Disease), Fiocruz. 52p.

Lent, H., \& Wigodzinsky, P. (1979). Revision of the triatominae (Hemiptera: Reduviidae) and their significance as vectors of Chagas disease. Bulletin of the American Museum of Natural History, 163, 125-520.

Lorenzo, Marcelo G. et al. (2000). Microclimatic aspects of Triatoma brasiliensis habitat. Public Health Booklet, 16, S69-S74.

Lutz, A. O. (1919) Schistosomum mansoni, according to observations made in Brazil. Mem Inst Oswaldo Cruz, 11, $121-155$.

Magallón-Gastélum, E. et al. (1998). Distribución de los vectores de la enfermedad de Chagas Hemiptera: Reduviidae: Triatominae en el estado de Jalisco, México. Revista Biomédica, 9, 151-157.

Menezes, L. R. et al. (2019) Epidemiological overview of chagas disease in the state of Amazonas, from 2004 to 2014 . Revista de epidemiologia e controle de infecção. 9 (2) 116-121.

Neves, D. P.; Melo, A. L.; Lenardi, P. M.; \& Vitor, R. W. A. (2016) Parasitologia Humana. (13a ed.), Atheneu, 616p.

Pinto, L. S. et al. (1990) Observations on the viability of Trypanosoma cruzi in sugarcane juice. Journal of the Institute of Tropical Medicine, 32, (5), 325327.

Prado, S. P. T. et al. (2010) Evaluation of the microbiological and microscopic profile of sugarcane juice in natura commercialized by street vendors. Journal of the Adolfo Lutz, Institute (Impresso), 69 (1), 55-61.

Public health department of rio grande do norte - SESAP-RN. (2016). Investigation Points to Outbreak of Chagas Disease in Municipalities of RN in 2015. http://www.saude.rn.gov.br/Conteudo.asp?TRAN=ITEM\&TARG=111912\&ACT=\&PAGE=\&PARM=\&LBL=Materia 